\title{
Agromyces bauzanensis sp. nov., isolated from soil
}

Correspondence

Rosa Margesin

rosa.margesin@uibk.ac.at

\author{
De-Chao Zhang, ${ }^{1}$ Peter Schumann, ${ }^{2}$ Hong-Can Liu, ${ }^{3}$ Yu-Hua Xin, ${ }^{3}$ \\ Yu-Guang Zhou, ${ }^{3}$ Franz Schinner ${ }^{1}$ and Rosa Margesin ${ }^{1}$
}

\author{
${ }^{1}$ Institute of Microbiology, University of Innsbruck, Technikerstrasse 25, A-6020 Innsbruck, Austria \\ ${ }^{2} \mathrm{DSMZ}$ - Deutsche Sammlung für Mikroorganismen und Zellkulturen GmbH, Inhoffenstrasse 7B, \\ D-38124 Braunschweig, Germany \\ ${ }^{3}$ China General Microbiological Culture Collection Center and State Key Laboratory of Microbial \\ Resources, Institute of Microbiology, Chinese Academy of Sciences, Beijing 100101, PR China
}

\begin{abstract}
A Gram-stain-positive, aerobic bacterium, designated strain $B Z 41^{\top}$, was isolated from hydrocarbon-contaminated soil. Phylogenetic analysis based on 16S rRNA gene sequences showed that strain $\mathrm{BZ} 41^{\top}$ was related to members of the genus Agromyces and showed highest similarity with the type strain of Agromyces ramosus (96.8\%). The morphological, biochemical and chemotaxonomic characteristics of the new isolate were consistent with the description of the genus Agromyces. The cell-wall peptidoglycan of strain $\mathrm{BZ} 41^{\top}$ was of type $\mathrm{B} 2 \gamma$ and contained the amino acids 2,4-diaminobutyric acid, alanine, glycine and glutamic acid in an approximate molar ratio of $1.8: 0.7: 1.1: 1.0$. The predominant cell-wall sugars were galactose, glucose, mannose and rhamnose. Strain $B Z 41^{\top}$ had MK-12 and MK-11 as major menaquinones and contained anteiso- $\mathrm{C}_{15: 0}$ and anteiso- $\mathrm{C}_{17: 0}$ as major fatty acids. The genomic DNA G $+\mathrm{C}$ content of strain $B Z 41^{\top}$ was $69.7 \mathrm{~mol} \%$. On the basis of phenotypic characteristics and genotypic analysis, strain $B Z 41^{\top}$ is considered to represent a novel species of the genus Agromyces, for which the name Agromyces bauzanensis sp. nov. is proposed. The type strain is $\mathrm{BZ}^{\top} 1^{\top}\left(=\mathrm{DSM} 22275^{\top}=\right.$ CGMCC $\left.1.8984^{\top}\right)$.
\end{abstract}

The genus Agromyces was proposed by Gledhill \& Casida (1969) and its description was emended by Zgurskaya et al. (1992). At the time of writing, the genus comprises 19 recognized species, and many members of the genus are widespread in soil (Takeuchi \& Hatano, 2001; Li et al., 2003; Jurado et al., 2005a; Yoon et al., 2008). In the present study, we report on the characterization of a novel Agromyces-like bacterium isolated from soil from an industrial site contaminated with hydrocarbons.

Strain $\mathrm{BZ}_{4}{ }^{\mathrm{T}}$ was isolated from soil from an industrial site containing high levels of heavy oil located in Bozen, South Tyrol, Italy. Soil was collected under sterile conditions in spring 2008. Ten grams of soil was shaken with $90 \mathrm{ml}$ sterile $1 \%$ sodium pyrophosphate for $20 \mathrm{~min}$ at 150 r.p.m. Appropriate dilutions, prepared with sterile saline solution $(0.9 \% \mathrm{NaCl})$, were plated $(0.1 \mathrm{ml})$ on $\mathrm{R} 2 \mathrm{~A}$ agar plates (Reasoner \& Geldreich, 1985; $0.05 \%$ yeast extract, $0.05 \%$ peptone, $0.05 \%$ Casamino acids, $0.05 \%$ glucose, $0.05 \%$ starch, $0.03 \%$ sodium pyruvate, $0.03 \% \mathrm{~K}_{2} \mathrm{HPO}_{4}$ and $\left.0.005 \% \mathrm{MgSO}_{4}, \mathrm{pH} 7\right)$ that were incubated at $20{ }^{\circ} \mathrm{C}$.

The GenBank/EMBL/DDBJ accession number for the 16S rRNA gene sequence of strain $B Z 41^{\top}$ is FJ972171.

Results of two-dimensional TLC of the phospholipids and glycolipid of strain $B Z 41^{\top}$ are available as supplementary material with the online version of this paper.
One of the pure cultures was yellow pigmented and was designated strain $\mathrm{BZ} 41^{\mathrm{T}}$. Agromyces ramosus DSM $43045^{\mathrm{T}}$ and Agromyces humatus $\mathrm{CD}^{\mathrm{T}}$ (kindly provided by $\mathrm{Dr}$ Cesáreo Saiz-Jimenez, Instituto de Recursos Naturales y Agrobiologia, Seville, Spain) were used as reference strains.

DNA was extracted and purified as described by Sambrook et al. (1989). The gene encoding the 16S rRNA was amplified by PCR with two universal primers (Zhang et al., 2007). PCR products were cloned by using the pGEM-T easy vector systems (Promega) according to the manufacturer's instructions. Sequencing reactions and phylogenetic analysis were performed as described by Zhang et al. (2007). Phylogenetic analysis (Fig. 1) showed that strain $\mathrm{BZ}^{\mathrm{T}} 1^{\mathrm{T}}$ grouped with members of the genus Agromyces in the neighbour-joining tree. Levels of $16 \mathrm{~S}$ rRNA gene sequence similarity between strain $\mathrm{BZ}_{4} 1^{\mathrm{T}}$ and other strains used in the phylogenetic analysis were less than $96.8 \%$. Similar tree topologies were found in the tree generated with the maximum-parsimony algorithm (data not shown).

Strain $\mathrm{BZ}_{41}^{\mathrm{T}}$ was routinely cultured in low-strength R2A agar medium and was maintained as a suspension in skimmed milk $(10 \%, \mathrm{w} / \mathrm{v})$ at $-80{ }^{\circ} \mathrm{C}$. Cell morphology was examined by phase-contrast microscopy $(\times 1000)$ of cells grown on R2A agar plates at $25{ }^{\circ} \mathrm{C}$. Colony morphology was also observed on R2A agar plates. The Gram reaction was 


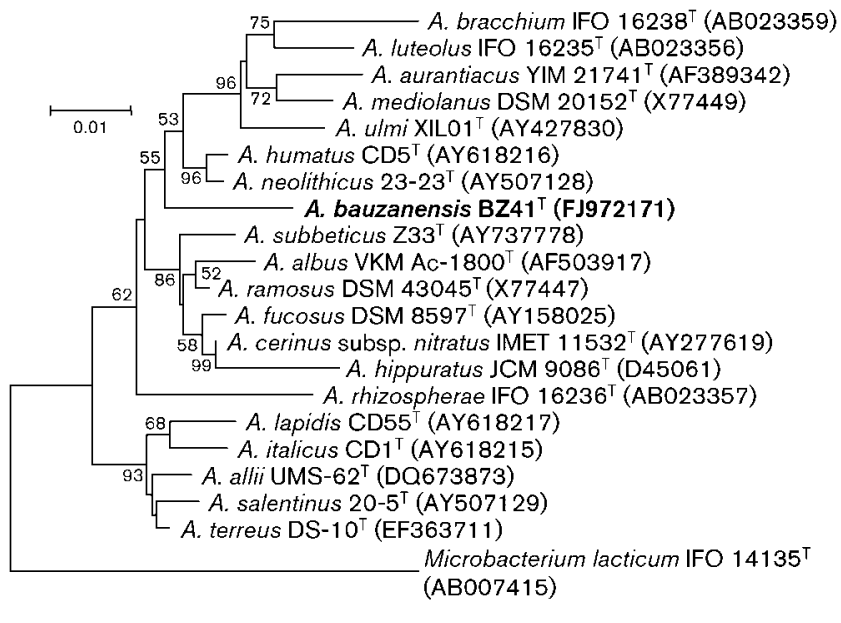

Fig. 1. Phylogenetic relationship between strain $B Z 41^{\top}$ and recognized members of the genus Agromyces based on $16 \mathrm{~S}$ rRNA gene sequences. Microbacterium lacticum IFO $14135^{\top}$ served as an outgroup. The tree was constructed by using the neighbour-joining method. Numbers at nodes represent levels of bootstrap support (\%) based on a neighbour-joining analysis of 1000 resampled datasets. GenBank accession numbers of $16 \mathrm{~S}$ rRNA gene sequences are given in parentheses. Bar, $1 \%$ sequence divergence.

tested via classical Gram staining and was confirmed by the $\mathrm{KOH}$ lysis test. Catalase activity was determined by bubble production in $3 \%(\mathrm{v} / \mathrm{v}) \mathrm{H}_{2} \mathrm{O}_{2}$, and oxidase activity was determined by using $1 \%(\mathrm{w} / \mathrm{v}) \quad N, N, N^{\prime}, N^{\prime}$-tetramethyl- $p$ phenylenediamine; these activities were tested by using cells grown for $24 \mathrm{~h}$ at $25^{\circ} \mathrm{C}$ on R2A agar plates. API strips [API 20 E, API 20 NE, API 50CH (B/E), API ZYM; bioMérieux] incubated at $25{ }^{\circ} \mathrm{C}$ were used according to the manufacturer's instructions to determine the physiological and biochemical characteristics as well as enzyme activities of strain $\mathrm{BZ}_{41}^{\mathrm{T}}$ and of the reference strains A. ramosus DSM $43045^{\mathrm{T}}$ and $A$. humatus $\mathrm{CD} 5^{\mathrm{T}}$. The assimilation of a number of carbon sources was additionally tested in liquid culture by supplementing $10 \mathrm{ml}$ of a $\mathrm{pH}$-neutral phosphate-buffered mineral salts medium with trace elements (Margesin et al., 2002) and various carbohydrates (final concentration $0.2 \%$, $\mathrm{w} / \mathrm{v}$ ) as the sole carbon source. Activities of $\beta$-galactosidase, amylase, protease and esterase lipase were additionally tested by using R2A agar plates supplemented with the appropriate enzyme substrates (Margesin et al., 2003). The API M system was used to evaluate cell motility. Growth at different temperatures $\left(1-37{ }^{\circ} \mathrm{C}\right)$ was assessed on R2A agar plates and in $\mathrm{R} 2 \mathrm{~A}$ liquid medium. Growth at $\mathrm{pH}$ 5-9 and salt tolerance $(0-5 \%, w / v, \mathrm{NaCl})$ were determined on R2A agar plates. Susceptibility to antibiotics was determined on R2A agar plates supplemented with various antibiotics; plates were incubated at $25{ }^{\circ} \mathrm{C}$. Growth under anaerobic conditions was determined after 3 days incubation at $25{ }^{\circ} \mathrm{C}$ in an anaerobic jar [containing Anaerocult A (Merck) to produce anaerobic conditions] on R2A agar plates as well as on R2A agar plates supplemented with $10 \mathrm{mM} \mathrm{KNO}_{3}$. Growth under microaerophilic conditions was assessed after 3 days at $25{ }^{\circ} \mathrm{C}$ on R2A agar plates that were incubated in a microaerophilic atmosphere containing 8-10\% (v/v) carbon dioxide and 5$7 \%(\mathrm{v} / \mathrm{v})$ oxygen; this atmosphere was generated in sealed jars containing Anaerocult C (Merck). Morphological, physiological and biochemical characteristics of strain $\mathrm{BZ}_{4} 1^{\mathrm{T}}$ are given in the species description and in Table 1. The strain was characterized by its inability to assimilate a wide range of carbon sources, although it shared with phylogenetically related members of the genus Agromyces the ability to hydrolyse aesculin and starch.

For analysis of the peptidoglycan structure and cell-wall sugars, cells of strain $\mathrm{BZ} 41^{\mathrm{T}}$ were cultured in shaken flasks of medium 830 (http://www.dsmz.de) at $28{ }^{\circ} \mathrm{C}$ for 3 days. Purified peptidoglycan preparations were obtained after disruption of cells by shaking with glass beads and subsequent trypsin digestion, according to the method of Schleifer (1985). The peptidoglycan structure was determined by using hydrolysates of purified cell walls according to Schleifer (1985).

Amino acids and peptides were separated by twodimensional ascending TLC on cellulose plates with the solvent systems given by Schleifer \& Kandler (1972). The molar ratio of amino acids was determined by GC as described by MacKenzie (1987). The peptidoglycan of strain $\mathrm{BZ}_{4}{ }^{\mathrm{T}}$ contained the amino acids 2,4-diaminobutyric acid, alanine, glycine and glutamic acid in an approximate molar ratio of $1.8: 0.7: 1.1: 1.0$. The quantitative amino acid composition of the peptidoglycan of strain $\mathrm{BZ}_{4} 1^{\mathrm{T}}$ was consistent with peptidoglycan type $\mathrm{B} 2 \gamma$ according to Schleifer \& Kandler (1972), which is usually found in members of the genus Agromyces. According to Sasaki et al. (1998), all recognized species of the genus Agromyces contain the L-isomer of diaminobutyric acid almost exclusively.

For analysis of cell-wall sugars, cell walls were hydrolysed in $0.5 \mathrm{M} \mathrm{H}_{2} \mathrm{SO}_{4}$ at $100{ }^{\circ} \mathrm{C}$ for $2 \mathrm{~h}$. $\mathrm{H}_{2} \mathrm{SO}_{4}$ was removed by shaking with $20 \% \mathrm{~N}, \mathrm{~N}$-dioctylmethylamine in chloroform according to Whiton et al. (1985) and the sugars in the hydrolysate were analysed by TLC on cellulose plates according to Staneck \& Roberts (1974). The main cell-wall sugars of strain $\mathrm{BZ} 41^{\mathrm{T}}$ were galactose, glucose, mannose and rhamnose. Smaller amounts of xylose were also detected.

For analysis of fatty acid methyl esters, cell mass of strain BZ4 ${ }^{\mathrm{T}}$ was harvested from trypticase soy agar plates $(3 \%$ trypticase soy broth, $0.3 \%$ yeast extract, $1.5 \%$ agar) after incubation at $28{ }^{\circ} \mathrm{C}$ for 4 days. Fatty acid methyl esters were prepared and extracted according to the standard protocol of the MIDI (Microbial Identification) system (Sasser, 1990). The predominant cellular fatty acids of strain $\mathrm{BZ}_{41}{ }^{\mathrm{T}}$ were anteiso- $\mathrm{C}_{15: 0}(46.4 \%)$, anteiso- $\mathrm{C}_{17: 0}$ $(21.1 \%)$, iso- $\mathrm{C}_{15: 0}(17.6 \%)$, iso- $\mathrm{C}_{16: 0}(7.0 \%), \mathrm{C}_{16: 0}$ $(4.4 \%)$ and iso- $\mathrm{C}_{17: 0}(2.8 \%)$. The fatty acid profile of strain $\mathrm{BZ}_{4} 1^{\mathrm{T}}$ differed from those of recognized Agromyces 
Table 1. Phenotypic characteristics that differentiate strain $B Z 41^{\top}$ from the type strains of recognized Agromyces species

Strains: 1, BZ41 ${ }^{\mathrm{T}}$; 2, A. albus VKM Ac- $1800^{\mathrm{T}}$ (data from Dorofeeva et al., 2003; Jurado et al., 2005b); 3, A. humatus CD5 ${ }^{\mathrm{T}}$ (Jurado et al., 2005b); 4, A. neolithicus 23-23 ${ }^{\mathrm{T}}$ (Jurado et al., 2005a); 5, A. ramosus IMET 11027 (Gledhill \& Casida, 1969; Groth et al., 1996; Dorofeeva et al., 2003). All strains are positive for hydrolysis of aesculin and starch and all often form branching hyphae. All are negative for endospore formation and motility, for hydrolysis of urea and Tween 80, for assimilation of citrate and for fermentative acid production from lactose and turanose. + , Positive; - , negative; w, weakly positive; $v$, variable; NA, no data available.

\begin{tabular}{|c|c|c|c|c|c|}
\hline Characteristic & 1 & 2 & 3 & 4 & 5 \\
\hline DNA G $+C$ content $(\mathrm{mol} \%)$ & 69.7 & 69.0 & 70.6 & 65.3 & 68.9 \\
\hline Optimum growth temperature $\left({ }^{\circ} \mathrm{C}\right)$ & $25-30$ & $26-28$ & 28 & 28 & 30 \\
\hline Growth at $10{ }^{\circ} \mathrm{C}$ & $+\neq$ & + & $+\ddagger \S$ & - & $+\ddagger \S$ \\
\hline Catalase reaction & + & + & $+\S$ & + & $-\S$ \\
\hline Nitrate reduction & - & - & $+\S$ & + & $-\S$ \\
\hline $\mathrm{H}_{2} \mathrm{~S}$ production & - & + & + & + & + \\
\hline \multicolumn{6}{|l|}{ Hydrolysis of: } \\
\hline Casein & - & + & + & + & - \\
\hline Gelatin & - & - & $+\S$ & + & $-\S$ \\
\hline \multicolumn{6}{|l|}{ Enzyme assays (API ZYM) } \\
\hline$\alpha$-Galactosidase & - & - & $-\S$ & + & $-\$$ \\
\hline$\beta$-Galactosidase & - & + & $+\S$ & - & $\mathrm{w} \S$ \\
\hline$\beta$-Glucuronidase & - & - & $w \S$ & + & $-\S$ \\
\hline$\alpha$-Mannosidase & - & - & $-\S$ & + & $-\S$ \\
\hline \multicolumn{6}{|l|}{ Assimilation (API 20NE) of: } \\
\hline Glucose & - & + & $+\S$ & NA & $+\S$ \\
\hline Maltose & - & + & $+\S$ & $\mathrm{NA}$ & $+\S$ \\
\hline Mannitol & - & + & $+\S$ & $\mathrm{NA}$ & $w \S$ \\
\hline$N$-Acetylglucosamine & - & NA & $+\S$ & NA & $-\S$ \\
\hline Sodium gluconate & - & NA & $+\S$ & NA & $-\S$ \\
\hline Malate & - & + & $+\S$ & - & $+\S$ \\
\hline L-Rhamnose & - & + & $+\S$ & - & $+\S$ \\
\hline
\end{tabular}

${ }^{*}$ Gal, Galactose; Glc, glucose; Man, mannose; Rha, rhamnose; Rib, ribose; Xyl, xylose.

†Whole-cell sugars.

‡Data obtained on R2A agar plates.

$\S$ Data from the present study using A. humatus $\mathrm{CD}^{\mathrm{T}}$ and A. ramosus DSM $43045^{\mathrm{T}}$.

species by the larger proportion of iso- $\mathrm{C}_{15: 0}$ and smaller proportion of iso- $\mathrm{C}_{16: 0}$ (Takeuchi \& Hatano, 2001; Li et al., 2003; Jurado et al., 2005a, b).

Respiratory quinones were extracted and purified according to Collins (1985) and were analysed by HPLC (Wu et al., 1989). Cellular polar lipids were extracted and analysed on silica gel plates (Kieselgel 60 F; Merck) by TLC (Kates,
1986). Strain $\mathrm{BZ}_{4} 1^{\mathrm{T}}$ contained MK-12 (61\%) and MK-11 $(34 \%)$ as the major menaquinones, with a minor amount of MK-13. The major polar lipids were diphosphatidylglycerol, phosphatidylglycerol and an unidentified glycolipid (see Supplementary Fig. S1, available in IJSEM Online).

The DNA G $+\mathrm{C}$ content of strain $\mathrm{BZ}_{4} 1^{\mathrm{T}}$, as determined with the thermal denaturation method (Sly et al., 1986) 
with Escherichia coli K-12 DNA as reference, was 69.7 mol\%. DNA-DNA relatedness tests were performed by using the optical renaturation method (De Ley et al., 1970) as modified by Huß et al. (1983). Tests were performed on a model Lambda $35 \mathrm{UV} / \mathrm{V}$ is spectrometer equipped with a temperature programme controller (Perkin-Elmer). On the basis of 16S rRNA gene sequence similarity, strain $\mathrm{BZ}^{\mathrm{T}}{ }^{\mathrm{T}}$ was related most closely to $A$. ramosus DSM $43045^{\mathrm{T}}(96.8 \%)$. However, the level of DNA-DNA relatedness between this reference strain and strain $\mathrm{BZ}^{\mathrm{T}}{ }^{\mathrm{T}}$ was only $26.6 \%$.

Based on the phenotypic, phylogenetic and genomic evidence presented, strain $B Z 41^{\mathrm{T}}$ is considered to represent a novel species of the genus Agromyces, for which the name Agromyces bauzanensis sp. nov. is proposed.

\section{Description of Agromyces bauzanensis sp. nov.}

Agromyces bauzanensis (bau.zan.en'sis. M.L. masc. adj. bauzanensis referring to Bauzanum, the medieval Latin name of Bozen/Bolzano, a city in South Tyrol, Italy, from where the type strain was isolated).

Cells form branching hyphae (0.3-0.5 $\mu \mathrm{m}$ long) that break up into irregular and rod-like, diphtheroid, non-motile fragments. Cells are Gram-stain-positive and aerobic; no growth occurs under anaerobic or microaerophilic conditions. Colonies on R2A agar are lemon yellow, round, convex, opaque and smooth with an entire margin; colony diameter is approx. $1 \mathrm{~mm}$. Growth on nutrient agar is weak; good growth occurs in $\mathrm{R} 2 \mathrm{~A}$ medium at $\mathrm{pH} 7-8$ and at $10-30{ }^{\circ} \mathrm{C}$, with fastest growth rates at $25-30{ }^{\circ} \mathrm{C}$; at $37{ }^{\circ} \mathrm{C}$, growth occurs on $\mathrm{R} 2 \mathrm{~A}$ agar plates but is very weak in liquid medium. No growth occurs at $42{ }^{\circ} \mathrm{C}$; growth at $1-5{ }^{\circ} \mathrm{C}$ is delayed and weak. Grows in the presence of $0-2 \%(\mathrm{w} / \mathrm{v})$ $\mathrm{NaCl}$. Catalase-positive; cytochrome oxidase is not produced. Negative for nitrate reduction and production of indole, $\mathrm{H}_{2} \mathrm{~S}$ and urease. Positive for hydrolysis of aesculin and starch and for activities of $\alpha$-galactosidase and leucine arylamidase. Negative for activities of gelatinase, arginine dihydrolase, lysine dihydrolase, ornithine dihydrolase, tryptophan deaminase, alkaline phosphatase, lipase (C14), $\alpha$-galactosidase, $\beta$-galactosidase, $\beta$-glucuronidase, $N$-acetyl$\beta$-glucosaminidase, $\alpha$-mannosidase, $\alpha$-fucosidase, trypsin and $\alpha$-chymotrypsin. Activities of esterase (C4), esterase lipase (C8) and valine arylamidase are weak. Sensitive to ampicillin and rifampicin $\left(10 \mu \mathrm{g} \mathrm{ml}^{-1}\right)$ as well as to penicillin G, kanamycin, streptomycin, tetracycline and chloramphenicol $\left(30 \mu \mathrm{g} \mathrm{ml}^{-1}\right)$. The following substrates are not assimilated: D-glucose, L-arabinose, D-mannose, Dmannitol, $\mathrm{N}$-acetylglucosamine, maltose, gluconate, citrate, malic acid, capric acid, adipic acid and phenylacetic acid. Negative for fermentative acid production from glucose, erythritol, D- and L-arabinose, ribose, L-xylose, adonitol, Dgalactose, lactose, fructose, mannose, L-sorbose, rhamnose, dulcitol, inositol, D-mannitol, D-sorbitol, turanose, Dlyxose, D-tagatose, D- and L-fucose, D-arabitol, potassium gluconate and 2-ketogluconate; positive for fermentative acid production from aesculin and weakly positive for fermentative acid production from glycerol, D-xylose, salicin, cellobiose, maltose, starch, glycogen and 5-ketogluconate. The cell-wall peptidoglycan is of type $\mathrm{B} 2 \gamma$ and contains the amino acids 2,4-diaminobutyric acid, alanine, glycine and glutamic acid. The predominant cell-wall sugars are galactose, glucose, mannose and rhamnose. The predominant cellular fatty acids are anteiso- $\mathrm{C}_{15: 0}$, anteiso$\mathrm{C}_{17: 0}$, iso- $\mathrm{C}_{15: 0}$ and iso- $\mathrm{C}_{16: 0}$. The major menaquinones are MK-12 and MK-11; a minor amount of MK-13 is also found. The major polar lipids are diphosphatidylglycerol, phosphatidylglycerol and an unidentified glycolipid. The DNA G $+C$ content of the type strain is $69.7 \mathrm{~mol} \%$.

The type strain, $B Z 41^{\mathrm{T}} \quad\left(=\mathrm{DSM} \quad 22275^{\mathrm{T}}=\mathrm{CGMCC}\right.$ $1.8984^{\mathrm{T}}$ ), was isolated from hydrocarbon-contaminated soil in Bozen, South Tyrol, Italy.

\section{Acknowledgements}

This research was supported by a grant from the Autonome Provinz Bozen, Südtirol. We thank Dr Cesáreo Saiz-Jimenez for providing the type strain of A. humatus and Gabriele Pötter (DSMZ) for analysis of cellular fatty acids.

\section{References}

Collins, M. D. (1985). Isoprenoid quinone analysis in classification and identification. In Chemical Methods in Bacterial Systematics, pp. 267-287. Edited by M. Goodfellow \& D. E. Minnikin. London: Academic Press.

De Ley, J., Cattoir, H. \& Reynaerts, A. (1970). The quantitative measurement of DNA hybridization from renaturation rates. Eur $J$ Biochem 12, 133-142.

Dorofeeva, L. V., Krausova, V. I., Evtushenko, L. I. \& Tiedje, J. M. (2003). Agromyces albus sp. nov., isolated from a plant (Androsace sp.). Int J Syst Evol Microbiol 53, 1435-1438.

Gledhill, W. E. \& Casida, L. E., Jr (1969). Predominant catalasenegative soil bacteria. III. Agromyces, gen. nov., microorganisms intermediary to Actinomyces and Nocardia. Appl Microbiol 18, 340-349.

Groth, I., Schumann, P., Weiss, N., Martin, K. \& Rainey, F. A. (1996). Agrococcus jenensis gen. nov., sp. nov., a new genus of actinomycetes with diaminobutyric acid in the cell wall. Int J Syst Bacteriol 46, 234239.

Huß, V. A. R., Festl, H. \& Schleifer, K. H. (1983). Studies on the spectrophotometric determination of DNA hybridization from renaturation rates. Syst Appl Microbiol 4, 184-192.

Jurado, V., Groth, I., Gonzalez, J. M., Laiz, L. \& Saiz-Jimenez, C. (2005a). Agromyces salentinus sp. nov. and Agromyces neolithicus sp. nov. Int J Syst Evol Microbiol 55, 153-157.

Jurado, V., Groth, I., Gonzalez, J. M., Laiz, L., Schuetze, B. \& SaizJimenez, C. (2005b). Agromyces italicus sp. nov., Agromyces humatus sp. nov. and Agromyces lapidis sp. nov., isolated from Roman catacombs. Int J Syst Evol Microbiol 55, 871-875.

Kates, M. (1986). Techniques of Lipidology, 2nd edn. Amsterdam: Elsevier.

Li, W.-J., Zhang, L.-P., Xu, P., Cui, X.-L., Xu, L.-H., Zhang, Z., Schumann, P., Stackebrandt, E. \& Jiang, C.-L. (2003). Agromyces aurantiacus sp. nov., isolated from a Chinese primeval forest. Int J Syst Evol Microbiol 53, 303-307. 
MacKenzie, S. L. (1987). Gas chromatographic analysis of amino acids as the $N$-heptafluorobutyryl isobutyl esters. J Assoc Off Anal Chem 70, 151-160.

Margesin, R., Zacke, G. \& Schinner, F. (2002). Characterization of heterotrophic microorganisms in alpine glacier cryoconite. Arct Antarct Alp Res 34, 88-93.

Margesin, R., Gander, S., Zacke, G., Gounot, A. M. \& Schinner, F. (2003). Hydrocarbon degradation and enzyme activities of coldadapted bacteria and yeasts. Extremophiles 7, 451-458.

Reasoner, D. J. \& Geldreich, E. E. (1985). A new medium for the enumeration and subculture of bacteria from potable water. Appl Environ Microbiol 49, 1-7.

Sambrook, J., Fritsch, E. F. \& Maniatis, T. (1989). Molecular Cloning: a Laboratory Manual, 2nd edn. Cold Spring Harbor, NY: Cold Spring Harbor Laboratory.

Sasaki, J., Chijimatsu, M. \& Suzuki, K. (1998). Taxonomic significance of 2,4-diaminobutyric acid isomers in the cell wall peptidoglycan of actinomycetes and reclassification of Clavibacter toxicus as Rathayibacter toxicus comb. nov. Int J Syst Bacteriol 48, 403410.

Sasser, M. (1990). Identification of bacteria by gas chromatography of cellular fatty acids, MIDI Technical Note 101. Newark, DE: MIDI Inc.

Schleifer, K. H. (1985). Analysis of the chemical composition and primary structure of murein. Methods Microbiol 18, 123-156.

Schleifer, K. H. \& Kandler, O. (1972). Peptidoglycan types of bacterial cell walls and their taxonomic implications. Bacteriol Rev 36, 407477.

Sly, L. I., Blackall, L. L., Kraat, P. C., Tian-Shen, T. \& Sangkhobol, V. (1986). The use of second derivative plots for the determination of mol\% guanine plus cytosine of DNA by the thermal denaturation method. J Microbiol Methods 5, 139-156.

Staneck, J. L. \& Roberts, G. D. (1974). Simplified approach to identification of aerobic actinomycetes by thin-layer chromatography. Appl Microbiol 28, 226-231.

Takeuchi, M. \& Hatano, K. (2001). Agromyces luteolus sp. nov., Agromyces rhizospherae sp. nov. and Agromyces bracchium sp. nov., from the mangrove rhizosphere. Int J Syst Evol Microbiol 51, 1529-1537.

Whiton, R. S., Lau, P., Morgan, S. L., Gilbart, J. \& Fox, A. (1985). Modifications in the alditol acetate method for analysis of muramic acid and other neutral and amino sugars by capillary gas chromatography-mass spectrometry with selected ion monitoring. J Chromatogr 347, 109-120.

Wu, C., Lu, X., Qin, M., Wang, Y. \& Ruan, J. (1989). Analysis of menaquinone compound in microbial cells by HPLC. Microbiology [English translation of Microbiology (Beijing)] 16, 176-178.

Yoon, J.-H., Schumann, P., Kang, S.-J., Park, S. \& Oh, T.-K. (2008). Agromyces terreus sp. nov., isolated from soil. Int J Syst Evol Microbiol 58, 1308-1312.

Zgurskaya, H. I., Evtushenko, L. I., Akimov, V. N., Voyevoda, H. V., Dobrovolskaya, T. G., Lysak, L. V. \& Kalakoutskii, L. V. (1992). Emended description of the genus Agromyces and description of Agromyces cerinus subsp. cerinus sp. nov., subsp. nov., Agromyces cerinus subsp. nitratus sp. nov., subsp. nov., Agromyces fucosus subsp. fucosus sp. nov., subsp. nov., and Agromyces fucosus subsp. hippuratus sp. nov., subsp. nov. Int J Syst Bacteriol 42, 635-641.

Zhang, D.-C., Wang, H.-X., Cui, H.-L., Yang, Y., Liu, H.-C., Dong, X.-Z. \& Zhou, P.-J. (2007). Cryobacterium psychrotolerans sp. nov., a novel psychrotolerant bacterium isolated from the China No.1 glacier. Int $J$ Syst Evol Microbiol 57, 866-869. 